Bulletin d'Histoire Contemporaine de

I'Espagne

$54 \mid 2020$

Les espaces du politique dans l'Espagne du Trienio liberal (1820-1823)

\title{
Gabriel Jackson (1921-2019)
}

Michael Seidman and University of North Carolina Wilmington

\section{(2) OpenEdition \\ Journals}

Electronic version

URL: http://journals.openedition.org/bhce/3336

DOI: 10.4000/bhce.3336

ISSN: 1968-3723

Publisher

Presses Universitaires de Provence

Printed version

Date of publication: 1 January 2020

ISSN: 0987-4135

Electronic reference

Michael Seidman and University of North Carolina Wilmington, « Gabriel Jackson (1921-2019) »,

Bulletin d'Histoire Contemporaine de l'Espagne [Online], 54 | 2020, Online since 01 July 2020, connection on 03 January 2021. URL : http://journals.openedition.org/bhce/3336 ; DOI : https://doi.org/10.4000/ bhce.3336

This text was automatically generated on 3 January 2021.

Bulletin d'histoire contemporaine de l'Espagne 


\section{Gabriel Jackson (1921-2019)}

\section{Michael Seidman and University of North Carolina Wilmington}

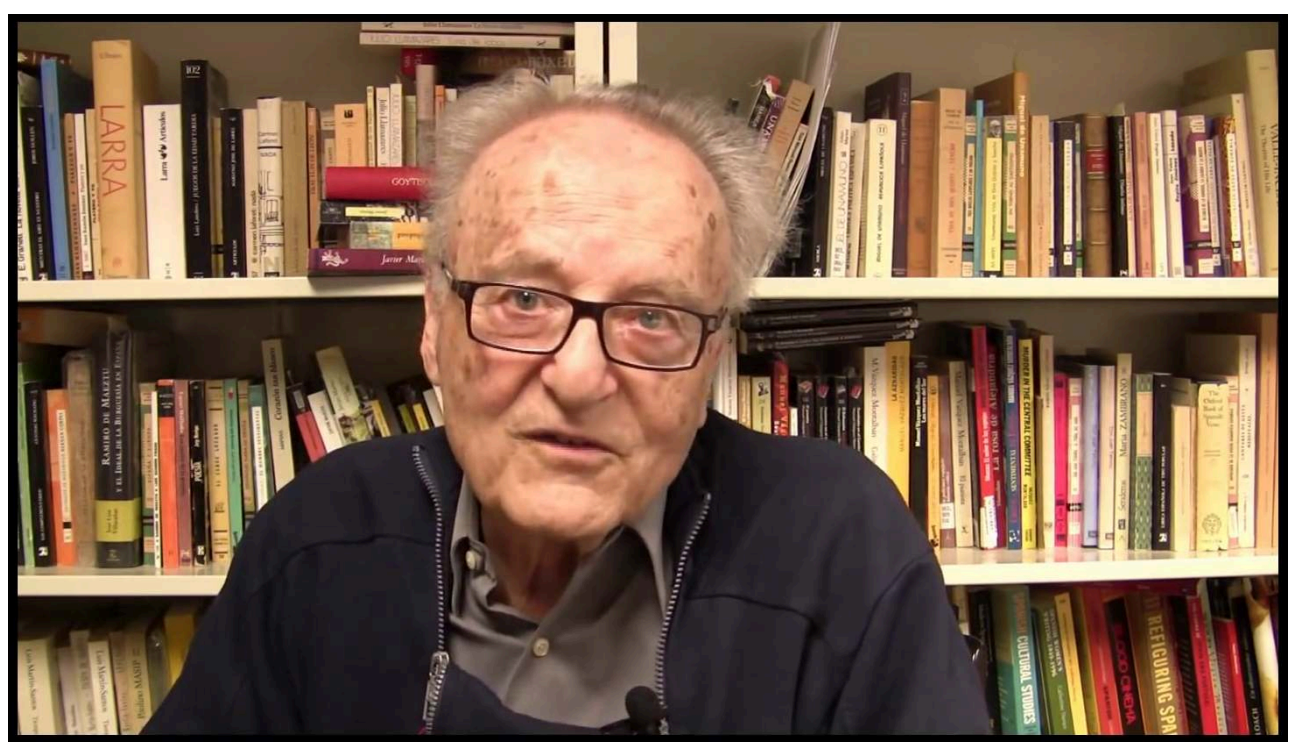

1 C S. Faber, Oberlin College, 2010

2 Gabriel Jackson, one of the most prominent and worthiest American hispanists and hispanophiles, died on 3 November 2019 at the age of 98 . He was born into a cultivated Jewish family in Mount Vernon, NY, in 1921. Gabe retained strong memories of the heated dinner-table discussions between his Socialist father and Communist older brother when the Spanish Civil War erupted in 1936. He graduated from Harvard College, where Perry Miller and F. O. Matthiessen were among his most influential teachers, in 1942 with a B.A. in history and literature. After Harvard, he spent several months in Mexico City living among Spanish Republican exiles. His subsequent fouryear army service included stints as an aircraft mechanic, photo interpreter, and cartographer. From 1946 to 1949 he taught English, Spanish, and -as a talented amateur musician-flute at Putney School in Vermont. After earning a M.A. at Stanford in 1950 with a thesis on the educational program of Second Spanish Republic during its first two years, 1931-1933, he began his doctoral studies at the University of Toulouse in 
southern France where he again encountered a large population of Spanish exiles. He later described his years in Toulouse as perhaps the most intellectually stimulating of his career. In 1952 under the supervision of Jacques Godechot, a distinguished specialist of the French Revolution and a pioneer of Atlantic history, he finished a dissertation on the work of Joaquín Costa, the turn-of-the-century Spanish regenerationist. As a Fulbright Fellow and GI Bill recipient, Jackson then embarked upon primary research in Spain which would result in his most important book, The Spanish Republic and the Civil War (Princeton, NJ, 1965), a winner of the 1966 Herbert Baxter Adams Prize of the American Historical Association. The book remains a masterful work of narrative political history that provides a sympathetic, but not uncritical, portrait of Spain's embattled first democracy. It was published in Spain only after the death of dictator Francisco Franco. Jackson describes the research experiences which led to the creation of this perceptive and judicious volume in his delightful Historian's Quest (New York, 1969).

3 From 1955 to 1960 he served as assistant professor of history at Wellesley College. From 1962 to 1965 he was associate professor of history at Knox College, and in 1965 he was appointed associate professor at University of California San Diego. During his years in California, he wrote The Making of Medieval Spain (New York, 1972). He retired from UCSD in 1983.

4 Following retirement, he lived primarily in Barcelona until his return to the US during the last decade of his life. He became an important public intellectual in his adopted country where he contributed regularly to its major daily, El País, and Revista de Libros, the Spanish equivalent to the Times Literary Supplement. He also produced the comprehensive Civilization and Barbarity in Twentieth-Century Europe (Amherst, NY, 1999); a biography Mozart: Vida y ficción (Salamanca, 2004); and Juan Negrín: Physiologist, Socialist, and Spanish Republican War Leader (Sussex, UK, 2010), a major and sympathetic portrait of the prime minister who ruled the increasingly desperate Second Republic in its final years.

His hospitality and generosity to younger scholars matched his intellectual acuity and deep culture. 